\title{
EVALUASI PENGGUNAAN ISOLATOR PADA SISTEM PERPINDAHAN PANAS SUATU ALAT HEAT EXCHANGER
}

\author{
Abdul Hamid ${ }^{1)}$, Indah Agus Setiorini ${ }^{2)}$ \\ 1Program Studi Teknik Pengolahan Migas Politeknik Akamigas Palembang, 30257, Indonesia \\ 21Program Studi Teknik Pengolahan Migas Politeknik Akamigas Palembang, 30257, Indonesia \\ Corresponding Author E-mail: hamid@pap.ac.iddan indahagussetiorini_sukarman@yahoo.co.id
}

\begin{abstract}
Heat exchanger is a device for transferring heat from a higher temperature fluid to a lower temperature fluid. In its application this tool is used to increase or decrease temperature, and also change the fluid phase, the process occurs by utilizing the process of heat transfer from high-temperature fluid to low-temperature fluid. In the industrial world the role of the heat exchanger is very important. This motivated the writer to raise this title into scientific work. This study aims to evaluate the results of heat loss when the heat exchanger uses isolators and without insulators. The analysis results obtained show a very significant difference where the amount of heat lost when the heat exchanger does not use a very large insulator is $655,7 \mathrm{BTU} / \mathrm{hr}$.ft, while the amount of heat lost when using an insulator is only 261,36 BTU / hr.ft . From the results of the heat loss analysis it can be concluded that the use of insulators in the heat exchange system is needed to reduce the amount of heat lost and can save energy use, where the amount of heat savings obtained is 394,34 BTU / hr.ft with insulation thickness $(\mathrm{X})=3,24$ inch.
\end{abstract}

Keywords: heat exchanger, isolation

Abstrak: Heat exchanger merupakan alat penukar panas yang digunakan sebagai media untuk memindahkan panas dari fluida yang bertemperatur lebih tinggi menuju fluida yang bertemperatur lebih rendah. Dalam aplikasinya alat ini digunakan untuk menaikkan maupun menurunkan temperatur, dan juga mengubah fase fluida, proses tersebut terjadi dengan memanfaatkan proses perpindahan kalor dari fluida bersuhu tinggi menuju fluida bersuhu rendah. Di dalam dunia industri peran dari heat exchanger sangat penting. Hal ini memotivasi penulis untuk mengangkat judul ini menjadi karya ilmiah. Penelitian ini bertujuan untuk mengevaluasi hasil panas yang hilang saat alat penukar panas tersebut menggunakan isolator dan tanpa isolator. Hasil analisa yang diperoleh menunjukkan perbedaan sangat signifikan dimana jumlah panas yang hilang saat heat exchanger tidak menggunakan isolator sangat besar yaitu 655,7 BTU/hr.ft, sedangkan untuk jumlah panas yang hilang saat menggunakan isolator hanya sebesar 261,36 BTU/hr.ft. Dari hasil analisa panas yang hilang tersebut dapat disimpulkan bahwa penggunaan isolator dalam sistem pertukaran panas sangat diperlukan untuk mengurangi jumlah panas yang hilang serta dapat menghemat penggunaan energi, dimana jumlah penghematan panas yang didapat sebesar 394,34 BTU/hr.ft dengan ketebalan isolasi $(X)=3,24$ inch. Kata kunci : heat exchanger, isolasi

\section{PENDAHULUAN}

Utilities berfungsi untuk menyediakan dan mengelola air, uap, listrik, udara kempaan yang semuanya merupakan tenaga yang sangat dibutuhkan oleh kilang minyak, perumahan dinas dan semua fasilitasnya. Untuk itu pengelolaan yang berdaya guna dan berhasil guna untuk menjamin kesinambungan tenaga mutlak diperlukan.

Tugas pokok yang dibebankan pada Utilities adalah: (Supriyadi,1987)

1. Membangkitkan tenaga listrik

2. Membangkitkan dan mendistribusikan tenaga uap

3. Mencukupi kebutuhan dan mendistribusikan udara kempaan
4. Mencukupi kebutuhan mendistribusikan air pendingin

5. Mencukupi kebutuhan mendistribusikan air minum

Dimana semua itu memerlukan proses produksi yang berkesinambungan untuk mendapatkan kebutuhan yang memenuhi persyaratan. Seluruh beban utilitas tersebut diatas tidak terlepas dari prinsip-prinsip perhitungan keseimbangan baik masalah energi/panas (heat balance) maupun bahan/material (mass balance) atau material balance. Proses itu memerlukan peralatan, bahan baku, dan bahan kimia serta tenaga kerja yang memerlukan biaya investasi. Maka untuk mendapatkan produksi kebutuhan tersebut di atas yang berdaya guna dan 
berhasil guna diperlukan suatu pengelolaan yang sebaik-baiknya. Khusus pada proses pendinginan atau sebaliknya agar pada proses perpindahan panas tidak banyak kehilangan energi diperlukan sarana yang memadai.

Pada dasarnya, energi panas merupakan suatu energi yang sangat luas pengaruh dan penggunaannya dalam industri-industri kimia. Bahkan tidak jarang masalah energi panas menjadi topik penting dalam setiap pembangunan industri kimia dan perhitunganperhitungan teknik kimia yang diperlukan. Dalam setiap proses produksi besarnya perhitungan energi panas di awali dari perhitungan material balance sehingga perhitungan keduanya dapat menentukan kapasitas produksi dan desain peralatan yang memadai baik ditinjau dari faktor kapasitas dan efisiensi peralatan produksi tersebut.

Dalam kehidupan sehari-hari banyak terlihat fenomena perpindahan panas dari fluida yang mempunyai temperatur lebih tinggi ke fluida yang mempunyai temperatur lebih rendah. Dalam dunia industri fenomena perpindahan panas tersebut dimanfaatkan untuk keperluan proses dengan menggunakan suatu alat yang biasa disebut sebagai penukar panas atau heat exchanger. Heat exchanger merupakan alat yang digunakan sebagai media untuk memindahkan panas dari fluida yang bertemperatur lebih tinggi menuju fluida yang bertemperatur lebih rendah. Dalam aplikasinya alat ini digunakan untuk menaikkan maupun menurunkan temperatur, dan juga mengubah fase fluida. Salah satu tipe heat exchanger yang banyak digunakan di dunia industri adalah shell and tube heat exchanger.

Tujuan perpindahan panas tersebut di dalam proses industri diantaranya adalah :

a) Memanaskan atau mendinginkan fluida hingga mencapai temperatur tertentu yang dapat memenuhi persyaratan untuk proses selanjutnya, seperti pemanasan reaktan atau pendinginan produk dan lain-lain.

b) Mengubah keadaan (fase) fluida seperti destilasi, evaporasi, kondensasi dan lainlain.

Di lapangan banyak dijumpai panas hilang yang terjadi disekitar dinding HE yang menyebabkan energi banyak terbuang. Sehubungan dengan hal tersebut kami selaku peneliti tertarik untuk menganalisa panas yang hilang pada HE yang terisolasi kalsium silikat dan alumunium jacket dengan $\mathrm{HE}$ tanpa isolasi.

\section{TEORI DASAR}

\subsection{Prinsip dan Teori Dasar Perpindahan Panas}

Panas adalah salah satu bentuk energi yang dapat dipindahkan dari suatu tempat ke tempat lain, tetapi tidak dapat diciptakan atau dimusnahkan sama sekali. Dalam suatu proses, panas dapat mengakibatkan terjadinya kenaikan suhu suatu zat dan atau perubahan tekanan, reaksi kimia dan kelistrikan. Proses terjadinya perpindahan panas dapat dilakukan secara langsung, yaitu fluida yang panas akan bercampur secara langsung dengan fluida dingin tanpa adanya pemisah dan untuk secara tidak langsung, yaitu bila diantara fluida panas dan fluida dingin tidak berhubungan langsung tetapi dipisahkan oleh sekat-sekat pemisah. Perbedaan temperatur merupakan potensi utama terjadinya perpindahan energi dalam bentuk panas yang sering atau lebih populer disingkat dengan perpindahan panas. Dari studi pustaka diperoleh bahwa ada 3 (tiga) cara perpindahan panas yaitu: konduksi, konveksi dan radiasi. Selain ketiga cara itu ada pula cara perpindahan panas gabungan.(Supriyadi,1987)

Dalam praktek terlalu sulit untuk membuktikan bahwa perpindahan panas hanya berlangsung dengan satu cara yang tersebut diatas. Perpindahan panas akan berlangsung bersamaan, sebagai contoh misalnya perpindahan panas pada pipa steam yang terisolasi, maka perpindahan panas tersebut akan berlangsung baik dari dinding dalam pipa ke permukaan isolasi maupun dari permukaan luar isolasi keudara sekitarnya, dimana perpindahan panas berlangsung secara konduksi, konveksi dan radiasi.

\subsection{Perpindahan Panas Secara Konduksi (Hantaran)}

Perpindahan panas jika panas mengalir dari tempat yang suhunya tinggi ketempat 
yang suhunya rendah, dengan media penghantar panas tetap (tanpa diikuti oleh gerak dari penghantar panas) sehingga jelas bahwa perpindahan panas secara konduksi adalah perpindahan panas yang dihantarkan oleh benda padat.

Perpindahan panas secara konduksi dasar Hukum Fourier dapat dinyatakan dengan persamaan : (D.Q Kern. Hal 2)

Dimana :

$$
\mathrm{Qk}=-\mathrm{kA} \frac{\mathrm{dT}}{\mathrm{dx}}
$$

$\mathrm{Qk}=$ laju perpindahan $\mathrm{kalor}(\mathrm{Btu} / \mathrm{hr})$

$\mathrm{k} \quad=$ konduktivitas thermal $\left(\mathrm{Btu} / \mathrm{ft} .{ }^{\circ} \mathrm{F}\right)$

$\mathrm{A} \quad=$ luas penampang yang tegak lurus dengan arah laju perpindahan kalor $\left(\mathrm{ft}^{2}\right)$

$\mathrm{dT} / \mathrm{dx}=$ gradient temperatur dalam arah $\mathrm{x}$ $\left({ }^{\circ} \mathrm{F} / \mathrm{ft}\right)$

\subsection{Perpindahan Panas Secara Konveksi}

Perpindahan panas yang dihantarkan melalui zat alir dari suatu pergerakan molekulmolekul yang dapat berupa zat cair atau gas.

Perpindahan panas secara konveksi ada dua macam :

a. Konveksi bebas, dimana perpindahan panasnya secara alamiah, sebagai akibat beda massa jenis yang timbul akibat adanya perbedaan atau gradien temperatur pada fluida.

b. Konveksi paksaan, dimana perpindahan panasnya secara cepat karena adanya tenaga penggerak dari luar, apabila gerakan fluida ini disebabkan oleh paksaan peralatan dari luar seperti pompa, blower dan lain-lainnya

Mekanisme perpindahan panas secara konveksi ada beberapa tahap, yaitu :

1. Panas mengalir secara konduksi dari permukaan padat ke partikel-partikel fluida yang didekatnya.

2. Panas ini menaikkan temperatur fluida dan energi dalamnya. Kemudian partikelpartikel yang bertemperatur tinggi bergerak ke arah partikel-partikel yang bertemperatur lebih rendah sehingga mereka akan saling bercampur dan energi berpindah pula pada saat pencampuran ini.
3. Dengan demikian timbul aliran fluida dan energi secara simultan. Energi sebenarnya disimpan pula dalam partikel-partikel fluida dan diangkut sebagai akibat gerakan massa partikel-partikel tersebut. Laju perpindahan panas konveksi dari sebuah permukaan benda padat ke fluida yang berada di sekelilingnya.

Perpindahan panas secara konveksi dasar hukum Newton dapat dinyatakan dengan persamaan : (D.Q Kern. Hal 26)

Dimana :

$$
\mathrm{Q}_{\mathrm{c}}=\mathrm{h}_{\mathrm{c}} \cdot \mathrm{A} \cdot\left(\mathrm{T}_{\mathrm{w}}-\mathrm{T}_{s}\right)
$$

$\mathrm{Q}_{\mathrm{c}} \quad=$ laju perpindahan panas konveksi, $\mathrm{Btu} / \mathrm{h}$

$\mathrm{h}_{\mathrm{c}} \quad=$ koefisien perpindahan panas konveksi (Btu/h.ft $\left.{ }^{2}{ }^{\circ} \mathrm{F}\right)$

A $=$ luas permukaan perpindahan panas $\left(\mathrm{ft}^{2}\right.$ atau $\left.\mathrm{m}^{2}\right)$

$\mathrm{T}_{\mathrm{w}} \quad=$ temperatur permukaan padat $\left({ }^{\circ} \mathrm{F}\right.$ atau K)

$\mathrm{T}_{\mathrm{s}} \quad=$ temperatur fluida yang jauh dari permukaan benda padat $\left({ }^{\circ} \mathrm{F}\right.$ atau K)

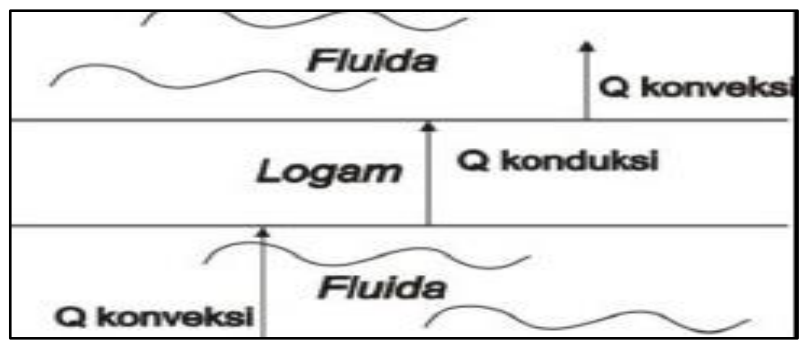

Gambar 2.1 Perpindahan Secara Konveksi dan Konduksi

\subsection{Perpindahan Panas Secara Radiasi}

Perpindahan panas yang terjadi karena pancaran / sinaran / radiasi gelombang elektromagnetik tanpa melalui media (tanpa melalui molekul). Suatu energi dapat dihantarkan dari suatu tempat ke tempat lainnya (dari benda panas ke benda yang dingin) dengan pancaran gelombang elektromagnetik (sinar kosmic, sinar gama, sinar $\mathrm{x}$, sinar ultra violet, sinar infra merah dll) dimana tenaga elektromagnetik ini akan berubah menjadi panas jika terserap oleh benda yang lain. Perpindahan panas secara 
Radiasi dasar Hukum Stefan - Boltzman dapat dinyatakan dengan persamaan :

$$
\mathrm{Qr}=\varepsilon . \sigma . \mathrm{A} . \mathrm{T}^{4}
$$

\section{Dimana:}

$$
\begin{aligned}
\text { Qr }= & \text { laju perpindahan panas Radiasi } \\
& (\mathrm{Btu} / \mathrm{h}) \\
\mathrm{T} & \text { suhu permukaan benda }\left({ }^{\circ} \mathrm{F} \text { atau } \mathrm{K}\right) \\
\mathrm{A} & \text { luas permukaan }\left(\mathrm{ft}^{2} \text { atau } \mathrm{m}^{2}\right) \\
\delta & \text { tetapan Stefan }- \text { Boltzman } \\
& \left(5,67 \times 10^{-8} \mathrm{~W} \cdot \mathrm{m}^{-2} \cdot \mathrm{K}^{-4}\right) \\
\varepsilon & =
\end{aligned}
$$

\subsection{Heat Exchanger}

Dalam kehidupan sehari-hari banyak terlihat fenomena perpindahan panas dari fluida yang mempunyai temperatur lebih tinggi ke fluida yang mempunyai temperatur lebih rendah. Dalam dunia industri fenomena perpindahan panas tersebut dimanfaatkan untuk keperluan proses dengan menggunakan suatu alat yang biasa disebut sebagai penukar panas atau heat exchanger. Heat exchanger merupakan alat yang digunakan sebagai media untuk memindahkan panas dari fluida yang bertemperatur lebih tinggi menuju fluida yang bertemperatur lebih rendah. Dalam aplikasinya alat ini digunakan untuk menaikkan maupun menurunkan temperatur, dan juga mengubah fase fluida. Salah satu tipe heat exchanger yang banyak digunakan di dunia industri adalah shell and tube heat exchanger.

Tujuan perpindahan panas tersebut di dalam proses industri diantaranya adalah :

a) Memanaskan atau mendinginkan fluida hingga mencapai temperatur tertentu yang dapat memenuhi persyaratan untuk proses selanjutnya, seperti pemanasan reaktan atau pendinginan produk dan lain-lain.

b) Mengubah keadaan (fase) fluida seperti destilasi, evaporasi, kondensasi dan lainlain.

\subsection{Pemilihan Isolator}

Dalam pemilihan isolator pada sistem perpindahan panas suatu alat heat exchanger sesungguhnya merupakan perencanaan untuk mengetahui keuntungan dalam pemakaian isolasi pada heat exchanger.
Berikut adalah beberapa alternatif material isolasi yang dapat digunakan, yaitu : (Supriyadi,1987)

a. Calsium silicate,

b. Diatomaceous silica,

c. Cellular glass,

d. Magnesium carbonate, dan

e. Serat-serat mineral.

Mengingat beragamnya material yang digunakan sebagai isolasi, hal ini menggambarkan bahwa jenis material isolasi yang digunakan memberikan kontribusi yang berbeda terhadap kehilangan panas (heat loss) dalam suatu sistem. Dalam penelitian ini, peneliti tidak membahas secara keseluruhan tentang jenis material isolasi yang digunakan. Namun peneliti hanya membahas tentang konstribusi kehilangan panas dari material Calsium Silicate. Pembahasan selanjutnya dalam mengestimasi ketebalan isolasi disamping memperhitungkan keselamatan, peneliti mencoba dengan perhitungan :

a. Kehilangan panas pada sistem alat heat exchanger tanpa isolasi,

b. Kehilangan Panas pada sistem alat heat exchanger terisolasi kalsium silikat + aluminium jacket.

c. Dilanjutkan dengan perhitungan jumlah penghematan panas yang hilang.

\subsection{Fungsi Isolasi}

Fungsi isolasi panas tersebut pada umumnya adalah sebagai berikut :

a. Untuk menghambat perpindahan panas dari dalam pipa atau peralatan lainnya sehingga bahan bakar dapat di hemat (fuel conservation),

b. Untuk mengendalikan dan mempertahankan suhu cairan, steam atau gas dalam pipa-pipa atau peralatan sehingga dapat dihindari terjadinya penurunan suhu (temperature control).

c. Untuk melindungi peralatan terhadap panas (fire protec).

d. Untuk melindungi pekerja terhadap panas (safety).

\subsection{Ketentuan Pemilihan Isolasi Panas}


Beberapa ketentuan yang perlu diperhatikan untuk pemilihan suatu bahan isolasi panas adalah: (Muntolib dan Rusdiyantoro, 2014)

a. Tidak mudah terbakar sampai pada batas limit tertentu, dalam arti bahan isolasi harus mempunyai ketahanan panas yang sesuai untuk menghadapi suhu kerja pada alat-alat yang panasnya cukup tinggi.

b. Tidak menimbulkan korosi terhadap permukaan yang di isolasi.

c. Tahan lama, susunan kimianya stabil.

d. Mempunyai thermal conductivity yang rendah dan ongkos pemasangan rendah.

e. Ketebalan yang sesuai untuk kondisi operasi.

\section{METODOLOGI PENELITIAN}

\subsection{Langkah-langkah Perhitungan}

1. Dasar Perhitungan Isolasi

a. Perpindahan panas melalui pipa tanpa isolasi

b. Perpindahan panas melalui pipa terisolasi Kalsium Silikat + Alumunium Jacket

2. Perhitungan

a. Kehilangan panas pada pipa HE tanpa Isolasi

b. Kehilangan panas pada pipa $\mathrm{HE}$ terisolasi Kalsium Silikat + Alumunium Jacket

c. Perhitungan Jumlah penghematan panas yang hilang.

3. Perhitungan Panas yang Hilang di Perpipaan

a. Pipa tanpa isolasi

Besarnya jumlah panas yang hilang melalui pipa tanpa isolasi dapat dihitung dengan persamaan sebagai berikut :

$$
Q=\frac{\pi\left(t_{s}-t_{a}\right)}{\frac{2,3}{2 K s} \log \frac{D 1}{D 2}+\frac{1}{h c . D 2}}
$$

Dimana:

$$
\begin{aligned}
& \mathrm{Q} \quad=\text { jumlah panas yang hilang melalui } \\
& \text { pipa tanpa isolasi (BTU/jam.ft) } \\
& \text { Ts } \quad=\text { suhu dinding dalam pipa }\left({ }^{\circ} \mathrm{F}\right) \\
& \mathrm{Ta}=\text { suhu Udara sekeliling pipa }\left({ }^{\circ} \mathrm{F}\right)
\end{aligned}
$$

$\mathrm{Ti}=$ suhu dinding luar pipa (silinder) $\left({ }^{\circ} \mathrm{F}\right)$

Ks $\quad=$ konduktifitas pipa steel (BTU/h.ft ${ }^{2}{ }^{\circ} \mathrm{F} . \mathrm{ft}^{-1}$ )

D1 = diameter dalam pipa (in)

D2 = diameter luar pipa (in)

$\mathrm{Hc}=$ combined koefisien dari Konveksi + Radiasi (BTU/h.. $\left.\mathrm{ft}^{2}{ }^{\mathrm{o}} \mathrm{F}\right)$

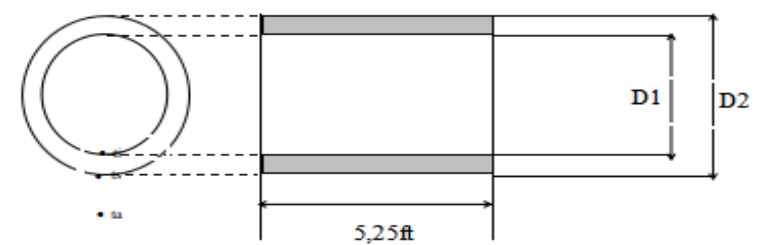

Gambar 2.2 Pipa Tanpa Isolasi

Untuk horizontal pipe besarnya hc dapat dihitung dengan persamaan sebagai berikut (Phenomena Heat Transfer, D.Q. Kern 1950, P-19, Tokyo):

Dimana:

$$
h c=0,5\left(\frac{t i-t a}{O D}\right)^{0,25}
$$

OD = diameter pipa (in)

4. Pipa Terisolasi Kalsium Silikat + Alumunium Jacket

Berdasarkan neraca panas:

$$
\mathrm{Q}_{\text {konduksikeluar }}=\left(\mathrm{Q}_{\text {konveksi }}+\mathrm{Q}_{\text {radiasi }}\right)_{\mathrm{keluar}}
$$

Maka jumlah panas yang hilang dapat dihitung dengan rumus sebagai berikut :

$$
Q_{k}=\frac{\left(\mathrm{t}_{\mathrm{s}}-\mathrm{t}_{\mathrm{i}}\right)}{\frac{2.3}{2 \mathrm{Ks}} \log \frac{\mathrm{D} 2}{\mathrm{D} 1}+\frac{2.3}{2 \mathrm{Ki}} \log \frac{\mathrm{D} 3}{\mathrm{D} 2}+\frac{2.3}{2 \mathrm{Ka}} \log \frac{\mathrm{D} 4}{\mathrm{D} 3}}
$$

Dimana:

$\mathrm{Q} \quad=$ jumlah panas yang hilang melalui pipa terisolasi kalsium silikat + aluminium jacket (BTU/h.ft)

$\mathrm{Ki}=$ thermal conduktivity isolasi kalsium silikat(BTU/h. $\left.\mathrm{ft}^{2} .{ }^{\circ} \mathrm{F} . \mathrm{ft}^{-1}\right)$

K.al = thermal conduktivity al. jacket (BTU/h.ft ${ }^{2}{ }^{\circ} \mathrm{F} . \mathrm{ft}^{-1}$ )

$\mathrm{D}_{3}=$ diameter luar isolasi kalsium silikat (in) 
$\mathrm{D}_{4}=$ diameter luar pembungkus al. jacket (in)

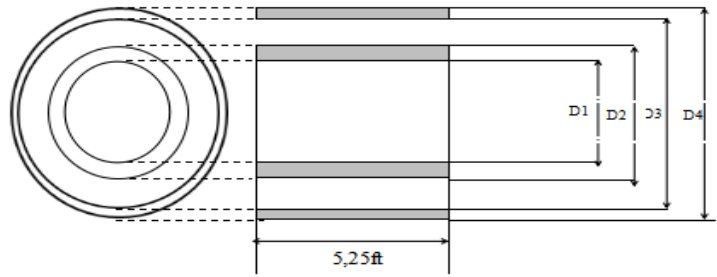

\section{Gambar 2.3 PipaTerisolasi Kalsium Silikat dan Alumunium Jacket}

Perpindahan panas secara konveksi dan radiasi. Panas yang hilang dari permukaan pipa keudara bebas menempuh dua cara secara konveksi dan radiasi.

Perpindahan panas konveksi dapat dicari dengan persamaan :

Dimana:

$$
\mathrm{Qc}=\mathrm{h} . \mathrm{A} \cdot \Delta \mathrm{t}
$$

Qc = panas yang hilang secara konveksi (D.Q. Kern page-77)

$\mathrm{h} \quad=$ koefisien perpindahan panas konveksi, (BTU/h.ft. $\left.{ }^{\circ} \mathrm{F}.\right)$

A $=$ luas permukaan perpindahan panas $\mathrm{ft}^{2}$

$\Delta \mathrm{t} \quad=\mathrm{ti}-\mathrm{ta}$

Dengan kondisi sirkulasi secara ilmiah besarnya koefisien heat transfer panas (h), yaitu :

$h=0,27\left(\frac{t i-t a}{D}\right)^{0,25}$

Dmana:

$\mathrm{D}=$ diameter luar silinder $(\mathrm{ft})$

Perpindahan panas secara radiasi dapat dirumuskan sebagai berikut :

Dimana:

$$
Q_{r}=\frac{\tau \cdot \mathrm{A}_{1}\left(\mathrm{t}_{i}{ }^{4}-\mathrm{t}_{\mathrm{a}}{ }^{4}\right)}{\frac{1}{\mathrm{E} 1}+\frac{A 1}{A 2}\left(\frac{1}{E 2}-1\right)}
$$

Qr $\quad=$ jumlah panas yang hilang secara radiasi (BTU/h.ft)

$\mathrm{Ta}=$ temperature absolut udara luar $(\mathrm{R})$

$\mathrm{Ti}=$ temperature absolut dinding luar isolasi $(\mathrm{R})$
A1 = luas permukaan luar silinder calcium silikat $\left(\mathrm{ft}^{2}\right)$

A2 = luas permukaan luar silinder Aluminium Jacket $\left(\mathrm{ft}^{2}\right)$

E1 = emisivity dari calcium silikat

E2 = emisivity dari aluminium Jacket

$\mathrm{T}=$ tetapam Bolzman constanta 0,173 x $10^{-8}\left(\mathrm{BTU} / \mathrm{h} . \mathrm{ft}^{2} . \mathrm{R}\right)$

\subsection{PERPINDAHAN PANAS SECARA KONVEKSI DAN RADIASI}

Perpindahan panas dari permukaan pipa keudara bebas dapat menempuh dengan cara konveksi dan radiasi. Perpindahan panas secara konveksi dapat dihitung dengan cara atau menggunakan rumus 4 dan 5 .

Perpindahan panas secara radiasi dapat dihitung dengan rumus sebagai berikut : (*Phenomena Transfer Transport, D.Q.Kern.1950.Hal.77, Mc. GrawHill.Tokyo)

$$
Q_{r}=\tau . \mathrm{E} \cdot \mathrm{A}\left(\mathrm{t}_{i}{ }^{4}-\mathrm{t}_{\mathrm{a}}{ }^{4}\right)
$$

3.3 URUTAN

PENYELESAIAN PERPINDAHAN PANAS

a. Perhitungan panas pada pipa steam/oli tanpa isolasi

Pelaksanaan perhitungan dilakukan dengan cara trial and error atas dasar pengecekan kembali harga Q untuk mendapatkan jumlah panas yang hilang.

b. Perpindahan panas pada pipaterisolasi Kalsium Silikat + Aluminium Jacket.

Perhitungan dilakukan dengan trial and error atas dasar neraca panas pada ti= $116,16{ }^{\circ} \mathrm{F}$ (batas suhu aman) untuk mendapatkan:

- Ketebalan isolasi, dan

- Jumlah panas yang hilang.

c. perhitungan jumlah penghematan panas yang hilang

Dengan membandingkan antara panas yang hilang pada pipa tanpa isolasi (poin a), dengan panas yang hilang pada pipa terisolasi Kalsium Silikat + Aluminium Jacket (poin b). 


\section{HASIL DAN PEMBAHASAN}

\subsection{Hasil Penelitian}

Dari perhitungan panas pipa tanpa isolasi dan terisolasi kalsium Silikat + aluminium jacket pada ti $116{ }^{\circ} \mathrm{F}$ dengan asumsi $\mathrm{D}_{3}$ untuk mendapatkan ketebalan isolasi (x), maka didapatkan hasil perhitungan pada lampiran 1 .

\subsection{Pembahasan}

Perhitungan dilakukan dengan cara trial and error berdasarkan neraca panas $\mathrm{Q}$ konduksi $=\mathrm{Q}$ konveksi $+\mathrm{Q}$ radiasi untuk mendapatkan ketebalan isolasi $(X)=3,24$ in. Untuk jenis isolasi yang digunakan adalah kalsium silikat. Hasil analisa yang diperoleh menunjukkan perbedaan sangat signifikan dimana jumlah panas yang hilang saat heat exchanger tidak menggunakan isolator sangat besar yaitu 655,7 BTU/h.ft, sedangkan untuk jumlah panas yang hilang saat menggunakan isolator hanya sebesar 261,36 BTU/h.ft. Dari hasil analisa panas yang hilang tersebut dapat simpulkan bahwa penggunaan isolator dalam sistem pertukaran panas sangat diperlukan untuk mengurangi jumlah panas yang hilang serta dapat menghemat penggunaan energi, dimana jumlah penghematan panas yang didapat sebesar 394,34 BTU/h.ft.

\section{KESIMPULAN DAN SARAN}

\subsection{Kesimpulan}

Utilitas di dalam industri migas khususnya dan di dalam industri besar lain pada umumnya sangatlah memegang peranan penting, karena tanpa tenaga listrik, tenaga uap, udara kempaan, air pendingin sebagaimana yang disediakan oleh utilities sangatlah sulit memproses minyak mentah (crude oil) menjadi fraksi-fraksi atau bahanbahan yang sangat kita butuhkan setiap hari. Dengan kata lain kelancaran operasi kilang dalam mengolah minyak mentah sangatlah tergantung dari kelancaran operasi utilitas salah satunya yaitu upaya penghematan panas di sistem alat penukar panas menggunakan isolator yang bisa membantu penghematan bahan bakar dan juga biaya yang dikeluarkan.

\subsection{Saran}

Disarankan perlu melakukan penghitungan panas yang hilang dengan isolator yang berbeda selain kalsium silikat misal menggunakan diatomaceous silica, cellular glass, magnesium carbonate atau serat-serat mineral.

\section{DAFTAR PUSTAKA}

Kern, D. Q. 1965. Process Heat Transfer. New York: International Student Edition, Mc. Graw-Hill Book.

Muntolib dan Rusdiyantoro. 2014. Analisa Bahan Isolasi Pipa Saluran Uap Panas Pada Boiler Untuk Meminimalisasi Heat Loss. Jurnal Teknik WAKTU Volume 12 Nomor 02 - Juli 2014 - ISSN : 1412-1867

Supriyadi, Y. 1987. Perencanaan Isolasi Perpipaan Distribusi Steam di UP III Sei Gerong. Hal. 40-45. Cepu: AKAMIGAS Cepu 
P-ISSN: 2089-5925 E-ISSN: 2621-9328

Antrant

Jurnal Teknik Patra Akademika

PA TRA

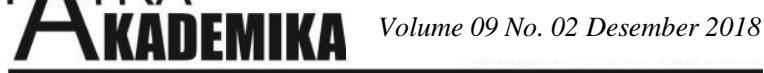

